\title{
Agmatin Biyokimyası: Şizofreni ve Depresyondaki Rolüne Bakış
}

\section{Biochemical Aspect of Agmatine; Role in Schizophrenia and Depression}

\author{
Erdem Çokluk ${ }^{1}$, M. Ramazan Şekeroğlu ${ }^{1}$, Emine Yılmaz ${ }^{2}$ \\ ${ }^{1}$ Sakarya Üniversitesi, Tip Fakültesi, Tibbi Biyokimya Anabilim Dal, Sakarya, Türkiye \\ ${ }^{2}$ Van Halk Sağlığı Laboratuvarı, Van, Türkiye \\ Yazıșma Adresi / Correspondence: \\ Erdem Çokluk \\ Sakarya Üniversitesi, Tip Fakültesi, Tibbi Biyokimya Anabilim Dalı, Sakarya, Turkey \\ T: +905064971615 E-mail: erdemcokluk@sakarya.edu.tr \\ Geliş Tarihi / Received : 19.09.2018 Kabul Tarihi / Accepted : 02.04.2019 \\ Orcid : \\ M Ramazan Şekeroğlu https://orcid.org/0000-0001-83836740 \\ Erdem Çokluk https://orcid.org/0000-0002-6205-5109
}

Öz

Agmatin imidazolin reseptör agonisti olup çok sayıda reseptörle etkileșebilen nöroprotektif, anti-enflamatuvar, anti-stres, anti-depresan özellikte, kognitif fonksiyonların düzenlenmesinde rol alan bir moleküldür. Agmatinin beyindeki inaktivasyonu, reuptake mekanizmaları ve enzimatik parçalanmayla gerçekleșmektedir. Geri alımı diğer nörotransmitterlerden farklı olarak sıcaklığa bağlı gerçekleşmekte ve sadece yüksek konsantrasyonlarda doygunluğa ulaşabilmektedir. Ayrıca, agmatinin streste arttığı, dolayısıyla majör depresyon hastalarında akut dönemde tedavi sonrası döneme göre plazma agmatin düzeylerinin daha yüksek olduğu da bildirilmiștir. Bununla birlikte șizofreni gelişmeden önceki süreçte agmatin eksikliğinden, șizofreni geliștikten sonraki dönemde ise agmatin artıșından bahseden çalıșmalar da literatürde mevcuttur. Bu derlemede agmatinin biyokimyası, șizofreni ve depresyondaki rolü ve nöroprotektif etkisi irdelenmiștir. ( Sakarya Tip Dergisi 2019, 9(2):206-212 )

Anahtar Agmatin; şizofreni; depresyon; nöroprotektif etki. a molecule involved in the regulation of cognitive functions. Inactivation of the agmatine is mediated by reuptake mechanisms and enzymatic degradation in brain. Unlike other neurotransmitters, the reuptake depends on the temperature and can only reach high concentrations of saturation. In addition, it was reported that agmatine increased in stress and therefore plasma agmatine levels were higher in patients with major depression compared to the post-treatment period in the acute phase.However, it is also reported in the literature that there is a lack of agmatine before the onset of schizophrenia and an increase in agmatine after the onset of schizophrenia. In this review, the biochemistry of agmatine, its role in schizophrenia and depression and its neuroprotective effect are examined. ( Sakarya Med J 2019, 9(2):206-212).

Keywords Agmatine; schizophrenia; depression; neuroprotective effect 


\section{GİRIş}

Agmatin (4- [aminobütil] guanidin), imidazolin reseptör agonisti olup çok sayıda reseptörle etkileşebilmektedir; nöroprotektif, anti-enflamatuvar, anti-stres, anti-depresan özelliklerinin olması, kognitif fonksiyonların düzenlenmesinde rol alması, morfin tolerans ve bağımlılığını önleyici özellikleri nedeniyle psikiyatri alanında ümit verici bir moleküldür. ${ }^{1}$ Agmatin başlangıçta imidazolin reseptörleri ve $\alpha 2$-adrenoseptörler için endojen bir ligand olarak dikkat çekmiştir. ${ }^{2}$ Ancak bu reseptörlere bağlanmadan da büyük bir terapötik potansiyel sergileyen çeşitli fizyolojik ve farmakolojik etkilere neden olmaktadır. Mevcut derlemede, agmatin'in yapısı biyosentezi, inaktivasyonu, dağılımı hakkında kapsamlı bilgi verilmiştir. Özellikle şizofreni ve depresyondaki rolü ve potansiyel klinik uygulaması tartışılmıştır.

\section{Keșfi ve Tarihsel Süreci}

İlk kez 1910 yllında Alman bilim adamı Albrecht Kossel tarafından bakteri, bitki ve omurgasızlarda keşfedilen agmatinin fonksiyonu, 1980'li yıllardan sonra anlaşılabilmiştir. ${ }^{3}$ 1994 yılında yapılan imidazolin reseptörleri için endojen ligand araştırmalarında beyin dokusundaki spektroskopik analizlerde agmatin varlığı gösterilmiştir. ${ }^{4}$ Agmatinin tarihsel süreci şekil l'de özetlenmiştir. ${ }^{5}$

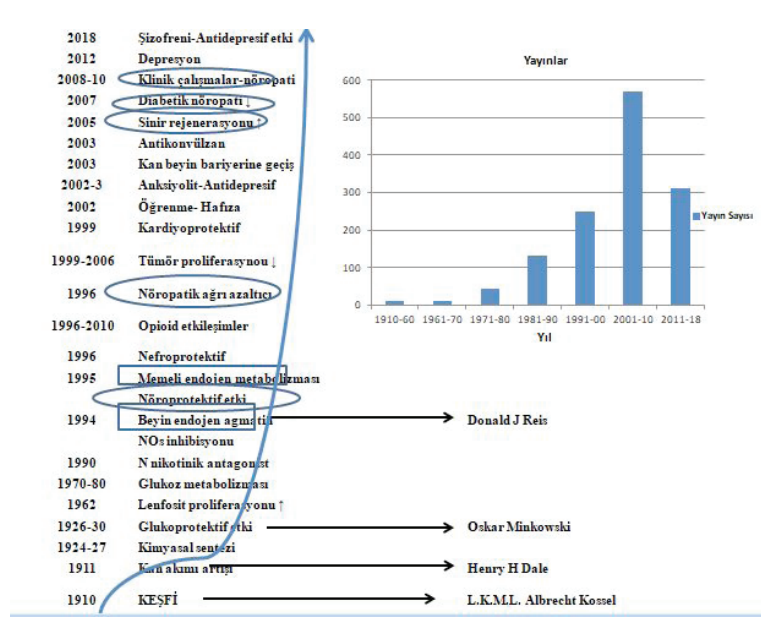

Şekil 1'de görüldüğü üzere Kossel'in 1910 yılındaki keşfinden itibaren 20. yüzyılın büyük bir bölümüne kadar agmatinle ilişkili çok fazla çalışmaya rastlanmamaktadır. Kossel'in keşfinden 10 yıl sonra Birinci Dünya Savaşı sıralarında araştırmalar Oskar Minkowski’nin kliniğinde devam etmiş ve daha çok potansiyel nontoksik antidiyabetik aminoguanidin analoğu olarak araştırılmıştır. 1960’larda agmatinin lenfosit ve timus hücrelerinin proliferasyonunu uyarabileceği bulunmuştur. 1970 ve 1980 yıllarında ise agmatinin glukoprotektif etkilerini açığa çıaran birkaç çalışma yapilmıştır. Buna ek olarak 1980’lerin sonunda Loring $^{5}$ tarafından bir radyo işaretleyici olan $[3 \mathrm{H}]$-agmatin kullanılarak agmatinin nöronal nikotinik reseptör antagonisti olduğu gösterilmiştir. Ancak bu son buluş çok fazla ilgi oluşturmamıştır. Agmatin için çı̆̆ır açan asıl keşif; Reis ve ark. tarafından 1994 yılında yapılmış olup agmatinle ilgili çalışmaların hızlı artışı bundan sonra olmuştur.4 20122018 yılları arasında agmatinle ilgili yapılan 312 çalışmanın 27 tanesi depresyon, 6 tanesi de şizofreni ile ilgilidir.

\section{Yapısı, Sentezi ve Yıkılımı}

Agmatin (guanidobutanolamin), L-arjininden dekarboksilasyonla oluşan katyonik bir amindir. Şekil 2'de agmatin molekülünün uzaysal dizilimi gösterilmiştir. L-arjininin enzimatik dekarboksilasyonu mitokondriyal bir enzim olan arjinin dekarboksilaz (ADC) aracilığıyla gerçekleşmektedir. ${ }^{6-9}$

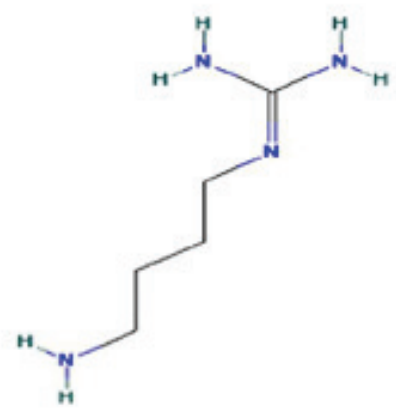

Sekall 2. Asmotinin kinyasal yapts 
Agmatinin beyindeki inaktivasyonu, reuptake mekanizmaları ve enzimatik parçalanma yolu ile gerçekleşmektedir. Geri alımı diğer nörotransmitterlerden farklı olarak sıcaklığa bağlı gerçekleşmekte ve sadece yüksek konsantrasyonlarda doygunluğa ulaşabilmektedir. Bu geri alım, Na-K ATPaz inhibisyonundan etkilenmemekte; sadece $\mathrm{Ca}+2$ kanal blokerleri ile inhibe edilebilmektedir. Agmatin hücreye voltaj bağımlı iyon kanalları yoluyla girebilmektedir. ${ }^{3}$ İnaktivasyonunda diğer bir yol olan agmatinaz ile enzimatik parçalanma sonucu poliamin biyosentezinde önemli bir öncül olan pütresin ve üre oluşmaktadır. Pütresinden de spermin ve spermidin sentezlenmektedir., ${ }^{3,510}$ Agmatini parçalayan diğer bir enzim ise diamin oksidaz olup reaksiyon sonucunda guanido butanoik asit oluşmaktadır. ${ }^{7}$ Agmatinin biyosentez ve yıkılımı şekil 3'te gösterilmiştir. ${ }^{5}$

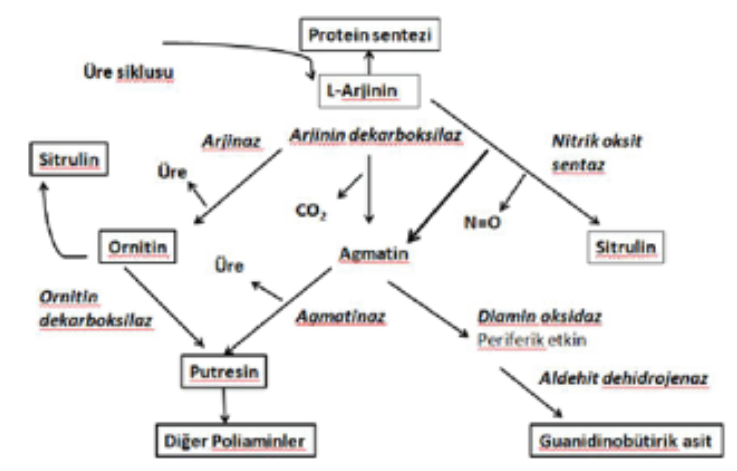

Sokal 3. Agmusinin byoscater ve yikam

\section{Biyolojik Aktivitesi ve Doku Dağılımı}

Biyolojik olarak aktif bir madde olan agmatin, imidazolin ve $a 2$ adrenerjik reseptörlere yüksek bir afinite ile bağlanmaktadır ${ }^{10}$. Rat beyninde nonadrenerjik imidazolin ve bazı a2 adrenerjik reseptörler üzerine klonidin benzeri etki gösterdiği de bildirilmiştir. ${ }^{11}$ Memeli beyninde klonidini bağlandığı bölgeden uzaklaştırdığı için klonidin yer değiștirici madde (clonidine displacing substance) olarak tanımlanmaktadır. ${ }^{3}$ Aynı zamanda N-metil D-aspartat (NMDA) reseptörleri gibi reseptöre bağımlı kalsiyum kanallarını bloke ederek antagonist etki de göstermektedir., ${ }^{1,12}$ Nikotinik kolinerjik ve serotonerjik 5-HT3 reseptörler gibi iyonotropik reseptör kanallarını bloke ettiği de bildirilmiștir. ${ }^{1}$ Agmatin, beyinde nörotransmitter olarak fonksiyon göstermesinin yanında fizyolojik konsantrasyonlarda nöronal nitrik oksit sentazın da inhibitörüdür. ${ }^{13,14}$ Luteinizan hormon salınımının hipotalamik kontrolü ve mideden gastrik sekresyon salınımı üzerine uyarıcı etkisinin olduğu bilinmektedir. ${ }^{1}$ Adrenal medullanın kromaffin hücrelerinden adrenalin ve nöradrenalin salınımı, renal sodyum ekskresyonu ve pankreatik hücrelerden insülin salınımının modülasyonuna katkıda bulunmaktadır. ${ }^{3,15}$ Bununla birlikte adipoz dokuda antilipolitik etkisi ve vasküler düz kas hücrelerinde proliferasyonun inhibisyonu etkisi de bilinmektedir. ${ }^{3}$ Yapılan çalışmalarda agmatinin lokomotor fonksiyonları iyileștirdiği ve spinal kord yaralanması sonrası gelişen doku hasarını azalttığ bildirilmektedir. ${ }^{5} \mathrm{Ag}$ matin tedavisinin ratlarda gelişen iskemik beyin hasarı ve erişkin ratlardaki spinal kord yaralanmalarında nöroprotektif olduğu da ifade edilmektedir. ${ }^{12}$ Yine bir başka çalışmada global serebral iskemi oluşturulan ratlarda ekzojen verilen agmatinin, nöroprotektif olan endoteliyal nitrik oksit sentaz (eNOS) yapımını artırırken toksik etkileri olan indüklenebilir nitrik oksit sentaz (iNOS) ve matriks metalloproteaz-9 konsantrasyonlarında azalma meydana getirerek koruyucu etki oluşturduğu ifade edilmektedir. ${ }^{16}$ Agmatin, memeli dokularına yaygın bir şekilde dağılmaktadır. En yüksek konsantrasyon başta mide olmak üzere aort ve ince bağırsaklarda; daha düşük konsantrasyonlarda ise dalak, adrenal bez, iskelet kası ve beyinde (bölgesel olarak korteks ve serebellumda) analiz edilmiştir., ${ }^{47}$

Rat beyindeki agmatinin bölgesel lokalizasyonu incelendiğinde agmatin ekspresyonunun son derece kisitlı olduğu, nöronal ağın esas olarak rostral beyin sapında ve ön beyinde olduğu gözlenmiştir. ${ }^{18}$ Ratlarda agmatine benzer şekilde Arginin dekarboksilazın varlığı da serebral korteks ve hipokampusta doğrulanmıştır. ${ }^{19}$ Agmatinazın beyindeki dağılımı heterojendir. En yüksek aktivite hipotalamusta; sonra medulla oblongata ve hipokampusta, en düşük aktivite ise striatum ve serebral kortekste tanımlanmıştır. ${ }^{20}$ Agmatinin iNOS süpresyonu ve NO inhibisyonundaki ro- 
Sakarya Tip Dergisi 2019;9(2):206-212

ÇOKLUK ve Ark., Agmatin Biyokimyası: Șizofreni ve Depresyondaki Rolüne Bakış

lünü gösteren mekanizmalar şekil 4’te gösterilmiştir. ${ }^{5}$

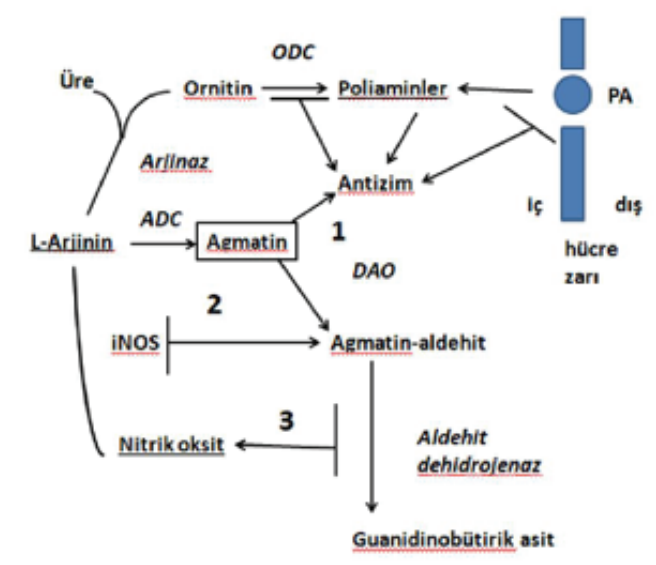

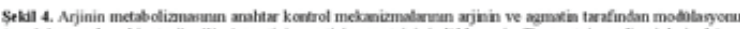

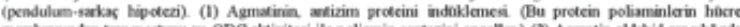

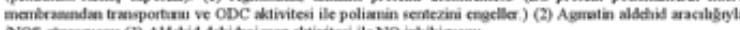

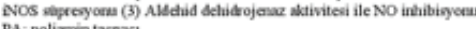

PA: polianm tappoi

Öğrenme ve bellek süreçleri ile ilgili yapılan bellek değerlendirme çalışmalarında, agmatinin beynin bellek ile ilişkili bölgelerinde \%85 oranında arttı̆̆ı bildirilmiştir ${ }^{1}$. Yine morfin ve alkol yoksunluk belirtilerinin çoğunu hafiflettiği gözlenen agmatinin, bu etkisinin NOS inhibisyonu veya NMDA antagonizması ile ilişkili olabileceği öne sürülmektedir. ${ }^{9}$

Agmatinin nörotransmitter ve nöromodülatör olarak işlevleri Tablo I'de belirtilmiştir. ${ }^{7}$

Agmatinin antidepresan, antikonvülzan, anksiyolitik etkilerle ilişkili olduğu bilinmektedir. ${ }^{7}$ Ekzojen agmatin antidepresan etkisini NMDA, a2 adrenerjik reseptörler, imidazolin, 5HT1A/1B, 5HT2, L-arjinin-NO yolu, potasyum kanalları ve opioid sistemleri aracılığıyla oluşturmaktadır. Ancak ekzojen uygulanan agmatin ile endojen salınan agmatinin nöronal sistem modülasyonu arasındaki ilişki henüz net değildir. ${ }^{6}$ Agmatinin düşük dozlarda beyinde bazı koruyucu etkileri olduğu ve merkezi sinir sistemi (MSS) hastalıklarının tanı ve tedavisinde rol alabileceğine dair çalışmalar olsa da, bu konu henüz araştırma aşamasındadır. ${ }^{9}$ Ekzojen agmatinin potansiyel klinik etkileri Tablo II'de verilmiştir. ${ }^{6}$

\begin{tabular}{|c|c|}
\hline \multicolumn{2}{|c|}{$\begin{array}{l}\text { Tablo I. Bir nörotransmitter veya nöromodülatör olarak } \\
\text { agmatin }\end{array}$} \\
\hline $\begin{array}{l}\text { BİR NÖROTRANSMİTTERIN } \\
\text { TANIMLAYICI ÖZELLIKLERİ }\end{array}$ & AGMATİN'İN ÖZELLİKLERİ \\
\hline Nöronlarda sentezlenir. & $\begin{array}{l}\text { Arjinin dekarboksilaz nöron } \\
\text { ve glia hücrelerinde mevcut- } \\
\text { tur. Agmatinin perikarya, } \\
\text { dentritler ve akson termi- } \\
\text { nallerinde lokalize olduğu } \\
\text { immunositokimyasal olarak } \\
\text { gösterilmiştir. }\end{array}$ \\
\hline Presinaptik salınım gösterir. & $\begin{array}{l}\text { Ca+2 bağımlı depolarizasyon } \\
\text { ile salınır. Sinaptozomlarda va- } \\
\text { zopressin ve glutamatla birlikte } \\
\text { paketlendiği gösterilmiştir. }\end{array}$ \\
\hline Sinirsel uyarımı taklit eder. & Bilinmiyor. \\
\hline $\begin{array}{l}\text { Spesifik etkileri ilaçlar } \\
\text { tarafından bloke edilebilir veya } \\
\text { gerçekleştirilebilir. }\end{array}$ & $\begin{array}{l}\text { İmidazolin için muhtemel } \\
\text { antagonist }\end{array}$ \\
\hline Reseptörler üzerine etkir. & $\begin{array}{l}\text { NMDA-r, } \alpha 2 \text {-adrenoseptor, } \\
\text { imidazolin, nikotinik, sero- } \\
\text { tonin 5-HtT3 ve voltaj kapılı } \\
\text { reseptörler }\end{array}$ \\
\hline $\begin{array}{l}\text { Belli nöron popülasyonlarında } \\
\text { mevcuttur. }\end{array}$ & $\begin{array}{l}\text { Hipokampus ve hipotala- } \\
\text { mus gibi çeşitli nöronlarda } \\
\text { dağılmıştır. }\end{array}$ \\
\hline Sinaptozomlarla içeri alınır. & Spesifik olarak hücrelere alınır. \\
\hline $\begin{array}{l}\text { Spesifik mekanizmalarla inak- } \\
\text { tive edilir. }\end{array}$ & $\begin{array}{l}\text { Agmatinaz (agmatin ürohidro- } \\
\text { laz) ile yıkılır. }\end{array}$ \\
\hline Diğer nöronal etkiler. & $\begin{array}{l}\text { Nöronal NOS ve indüklene- } \\
\text { bilir NOS' }{ }_{1} \text { inhibe eder. Ayrıca } \\
\text { nöradrenalin ve glutamat } \\
\text { salınımını da inhibe eder. }\end{array}$ \\
\hline
\end{tabular}

Tablo II. Ekzojen agmatinin potansiyel klinik etkileri

- Kanser terapisinde adjuvan tedavi

- İskemik ya da travmatik beyin hasarı ile spinal kord yaralanmasi tedavisi

- Postop ve nöropatik ağrı tedavisi

- Opiad bağımlılı̆̆ı tedavisi

- Antikonvülzan, antidepresan ve anksiyolitik ajan olarak kullanım

- Parkinson ve Alzheimer hastalıklarının tedavisi

- Vasküler hiperplazi ve hipertansiyon tedavisi

- Sepsis tedavisinde yararlı etki

- Karaciğer hastalıklarında üre sentezinin düzenlenmesi

- Dekompanse karaciğer sirozu tedavisi

- Antiemetik tedavi

- Glokom tedavisi

- Retinal hücre tamiri

- Diabetes Mellitus tedavisinde adjuvan terapi 


\section{Nöropsikiyatrik Rolü, Şizofreni ve Depresyon İlişkisi}

Nöropsikiyatrik bağlamda agmatin ile ilgili yapılan çalışmalar son yıllarda hız kazanmış, psikiyatrik açıdan şizofreni ve depresyonda agmatinin rolü incelenmiştir. Literatürde agmatinin şizofrenideki olası rolünü araştıran çalışmalar olmakla beraber, bu çalışmalar sonuçları açısından farklllıklar göstermektedir. Palsson ve ark. tarafından deneysel şizofreni modeli oluşturularak yapılan bir çalışmada agmatinin çeşitli dozlardaki fensiklidin uygulamasına karşı oluşan yanıtı özellikle $20 \mathrm{mg} / \mathrm{kg}$ dozlarda baskıladığı gösterilmiştir. ${ }^{21}$ Uzbay ve ark. tarafından yapılan bir diğer çalışmada ise yüksek dozda (160 mg/kg) uygulanan ekzojen agmatinin şizofreniye sebep olabileceği ve bu şekilde oluşan şizofreninin bilinen antipsikotiklerle engellenemediği öne sürülmüştür.22 Bu bilgiler ışığında agmatinin psikozların oluşumunda ve/veya şiddetinde önem arz eden endojen bir madde olabileceği düşünülmektedir. ${ }^{23}$

Şizofreni için risk faktörü olan 'maternal immün reaksiyon' geliştirilen ratlarda yapılan bir çalışmada prefrontal korteks, hipokampus ve serebellumda L-arjinin metabolizması ölçülmüş; L-arjinin, L-ornitin ve putresin seviyelerinde anlamlı ölçüde artış gözlenirken agmatin düzeyinde ise anlamlı ölçüde azalma gözlenmiştir. ${ }^{24}$ Bunun aksine Liu ve ark. tarafından 2016'da yayımlanan bir çalışmada şizofreni hastası bireylerde postmortem yapılan incelemede frontal kortekste L-arjinin seviyesinde anlamlı değişiklik olmasa da agmatin konsantrasyonunun ve arjinaz aktivitesinin önemli derecede arttığ 1 tespit edilmiştir. ${ }^{25}$ Bu bilgilerden yola çıkarak şizofreni gelişmeden önceki süreçte agmatin eksikliğinden, şizofreni geliştikten sonraki dönemde ise agmatin artışından bahsedilebileceği düşünülmektedir.

Agmatinin "anti-stres" etkisi olabileceği fikri ilk kez Streward ve McKay tarafından ortaya atılmışıtır. ${ }^{26}$ Arıcıoğlu ve ark. tarafından yapılan deneysel hayvan çalışmalarına bakıldığında, stres durumunda endojen agmatin üretiminin 5 kattan fazla arttığı, sistemik olarak uygulanan agmatinin düşük dozlarda bile anksiyolitik etki potansiyeli olduğu gösterilmiş; endojen bir madde olan agmatinin beyni stresin etkisine karşı korumak üzere arttığı sonucuna varılmıştır. ${ }^{27}$

Yine deneysel hayvan çalışmaları ile intraperitoneal (0.01$50 \mathrm{mg} / \mathrm{kg}$ ) uygulanan veya intrakranial ven yoluyla sıçanlara uygulanan agmatinin hem tek başına antidepresan etkisinin olabileceği hem de imipraminin antidepresan etkisini arttırdığı gösterilmiştir. ${ }^{28}$ Arıcıoğlu ve ark. çalışmasında agmatinin etkisinin doza bağımlı olarak artmadığı belirtilmiştir. $^{27}$

Agmatinin antidepresan etkisinin mekanizmasının araşt1rıldığı bir başka çalışmada, bu etkinin imidazolin reseptörleri aracılı̆̆g ile olabileceği görüşü ortaya atılmıştır. ${ }^{29}$ Budni ve ark. tarafından agmatinin etkisinin farklı potasyum kanalları aracılığıyla olabileceği, selektif serotonin reuptake inhibitörlerinin (SSRI) etkilerinin ise agmatinle potansiyalize olduğu belirtilmektedir. ${ }^{30}$ Taksande ve ark. tarafından SSRI’nin agmatin düzeylerini beyinde arttırabileceği ve bu etkinin arjinin dekarboksilaz inhibitörü D-arjinin tarafından tamamen bloke edilebileceği gösterilmiştir. ${ }^{31}$ Ancak aynı etki imidazolin reseptör antagonistleriyle gösterilememiştir.

Yapılan son çalışmalar duygudurum düzenlemesinde agmatinin rolünün olduğunu desteklemektedir. ${ }^{32-35}$ Agmatinin, stres durumlarında arttığı, dolayısıyla majör depresyon hastalarında akut dönemde tedavi sonrası döneme göre plazma agmatin düzeylerinin daha yüksek olduğu gösterilmiştir. ${ }^{1}$ Bunun aksine agmatinerjik sistemin disregülasyonu sonucu duygudurum değişiklikleri olabileceği belirtilmiş, deneysel hayvan çalışmalarında agmatinaz geninin upregülasyonu ile oluşan agmatinaz artışı ve buna bağlı gelişen agmatin defisitinin depresif fenotipe yol açtığ ileri sürülmüştür. ${ }^{34}$ Nitekim duygudurum bozuklukları ile ilişkili olarak yapılan postmortem bir çalışmada agmatinaz enzim ekspresyonunun arttığ tespit edilmişstir. ${ }^{32} \mathrm{Bu}$ çalışmaya göre bipolar ve unipolar bozukluğa sahip bireylerde postmortem olarak yapılan ölçümlerde agmatinaz ekspresyonunun önemli ölçüde arttığı saptanarak patoge- 
nezde agmatin degradasyonunun sorumlu olabileceği ifade edilmiştir. Ülkemizde 2012 yılında bildirilen bir vakada arjinin, ornitin ve lizin aminoasit takviyesi kullanımına bağlı eş zamanlı psikotik özellikli manik atak geçirdiği düşünülen vaka üzerinden bipolar bozukluk patogenezinde arjinin-nitrik oksit yolağı ve agmatinin olası rolü tartışılmış ve söz konusu vakada akut mani atağında asimetrik dimetil arjinin (ADMA) seviyelerinin yüksek saptanması sonucu; NO ve agmatinin psikotik belirtiler ile ilişkili olmasından varsayımla; arjinin-NO yolağı ile psikotik özellikli manik atak arasında bir ilişki olabileceği fikri öne sürülmüştür. ${ }^{36}$ Antidepresan ve nöroprotektif etkilerini inceleyen araştırmacılar tarafından agmatin, güncel bilgiler ışığında gelecek vaat eden makul bir antidepresan ajan olarak önerilmiş, ancak özellikle insanlarda güvenliğini ve etkinliğini sağlamak için daha fazla çalışmaya ihtiyaç olduğu vurgulanmıştır. ${ }^{20}$

Bipolar Bozukluğun oluş nedenleri, nörobiyolojisi ve nörokimyası şimdiye kadar yapılmış olan çalışmalarda tam anlamıyla açıklanamamıştır. Yaptığımız literatür taramalarında endojen antidepresan olarak yeni tanımlanmış bir nörotransmitter olan agmatinle ilgili Bipolar I bozukluk tanılı hastalar üzerinde yapılmış klinik bir çalışmaya da rastlanmamıştır. Biz de bu konuyla alakalı olarak Bipolar Bozukluk tanılı hastaların manik atak ve remisyon dönemlerinde ölçülen plazma agmatin düzeyi; agmatin sentez yolağındaki L-arjinin, arjinin dekarboksilaz ve agmatini degrede eden agmatinaz seviyelerini sağlıklı kontrol grubu ile karşılaştırdık. Ayrıca atak ve remisyon dönemlerindeki atak sayısına göre bu parametrelerdeki değişiklikleri de incelendik. Sonuç olarak Bipolar Bozukluk ile Agmatin ve onun metabolik yolağı arasında ilişki olabileceğini gösterdik. Çalışmamızın bulgularına göre bir duygudurum bozukluğu olan Bipolar bozuklukta manik atak dönemindeki hastalarda plazma agmatin düzeyinin, remisyon dönemi ve sağlıklı kontrol grupları ile karşılaştırıldığında yükselmiş olduğu gözlendi; bu değişime agmatinin sentez ve yıkım yolaklarındaki metabolik düzenlemelerin yol açabileceği düşünülmüştür. Dolayısıyla agmatinin bipolar bozukluk ve diğer psikotik bozuklukların patogenezinde prediktif değeri olabilecek bir potansiyele sahip biomarker olarak değerlendirilebileceğini, ancak bu konuda söz konusu çalışmamızın kapasitesini aşan, agmatinin etki mekanizmalarını belirgin bir şekilde aydınlatabilmek için geniş hasta gruplarında, daha uzun süreli ve kapsamlı çalışmalara ihtiyaç olduğunu düşünmekteyiz. ${ }^{37}$

\section{SONUÇ}

Agmatin yapısal olarak farklı birçok reseptör ile etkileşim gösteren nörotransmitter özellikleri barındıran bir moleküldür. Ayrıca hayvan çalışmalarında da gösterildiği gibi anksiyolitik ve anti depresan özelliklere de sahiptir. Veri tabanında agmatinin anti depresan olarak kullanıldığı tek bir çalışma mevcuttur. Bunlarla birlikte gerek hastalıkların daha iyi anlaşılması, gerekse de yeni tedavi yaklaşımlarının oluşturulmasında ümit verici bir moleküldür. Agmatin, eğer klinik çalışmalarda etkinliği ve güvenliği gösterilebilirse, terapötik bir ajan olma ya da psikotik bozuklukların patogenezinde prediktif değere sahip olma potansiyeline sahiptir.

Yazarlar herhangi bir çıkar ilişkisi olmadığını beyan etmektedirler. 
Sakarya Tip Dergisi 2019;9(2):206-212

ÇOKLUK ve Ark., Agmatin Biyokimyası: Şizofreni ve Depresyondaki Rolüne Bakış

\section{Kaynaklar}

1. Bozkurt N I, Utkan T, Arıcıoğlu F, Agmatinin Kognitif Fonksiyonlara Etkisinin Arașttrılması. MÜSBED, 2011.

2. Gerhard J. Molderings $\bigotimes$, Britta Haenisch, Agmatine (decarboxylated l-arginine): Physiological role and therapeutic potential, Pharmacology \& Therapeutics 133 (2012) 351-365

3. Gümrü S, Şahin C, Arıcıoğlu F, Yeni bir nörotransmitter/nöromodülatör olarak agmatine genel bir bakış. MÜSBED 2013.

4. Reis D J,Regunathan S, Is agmatine a novel neurotransmitter in brain? Trends Pharmacol. Sci., 2000. 21(5): p. 187-193.

5. Piletz J E, Aricioglu F, Cheng J-T, Fairbanks C A, Gilad V H, Haenisch B, Halaris A, et al., Agmatine: clinical applications after 100 years in translation. Drug Discov Today, 2013. 18(17): p. 880-893.

6. Molderings G J,Haenisch B, Agmatine (decarboxylated l-arginine): Physiological role and therapeutic potential. Pharmacol Ther., 2012. 133(3): p. 351-365.

7. Halaris A,Plietz J, Agmatine. CNS drugs, 2007. 21(11): p. 885-900.

8. Uzbay TI, The pharmacological importance of agmatine in the brain. Neurosci Biobehav Rev., 2012. 36(1): p. 502-519.

9. Uzbay T, Nörokimyasal İletim, Biyolojik Psikiyatri, Ișıł E, Editor. 2012, Sigma Publishing: İstanbul. p. 44-45.

10. Uzbay T, Şizofreni Tedavisinde Yeni Bir Hedef Agmatin ve Beyin Poliamin Sistemi. Turk Psikiyatri Derg, 2009. 12(4).

11. Zhao S, Xie C, Lu X, Liu Y-M, Determination of agmatine in biological samples by capillary electrophoresis with chemiluminescence detection. Journal of Chromatography B, 2006. 832(1): p. 52-57.

12. Zhao S, Feng Y, LeBlanc M H, Piletz J E, Liu Y-M, Quantitation of agmatine by liquid chromatography with laser-induced fluorescence detection. Anal. Chim. Acta, 2002. 470(2): p. 155-161.

13. Cofre J, Montes P, Vallejos A, Benítez J, García D, Martínez-Oyanedel J, Carvajal N, et al., Further insight into the inhibitory action of a LIM/double zinc-finger motif of an agmatinase-like protein. J. Inorg. Biochem., 2014. 132: p. 92-95.

14. Demady D R, Jianmongkol S, Vuletich J L, Bender A T, Osawa Y, Agmatine enhances the NADPH oxidase activity of neuronal NO synthase and leads to oxidative inactivation of the enzyme. Mol. Pharmacol., 2001. 59(1): p. 24-29.

15. Su C-H, Liu I-M, Chung H-H, Cheng J-T, Activation of I 2-imidazoline receptors by agmatine improved insulin sensitivity through two mechanisms in type-2 diabetic rats. Neurosci. Lett., 2009. 457(3): p. 125-128.

16. Mun C H, Lee W T, Park K A, Lee J E, Regulation of endothelial nitric oxide synthase by agmatine after transient global cerebral ischemia in rat brain. Anat Cell Biol, 2010. 43(3): p. $230-240$.

17. Raasch W, Regunathan S, Li G, Reis D, Agmatine, the bacterial amine, is widely distributed in mammalian tissues. Life Sci., 1995. 56(26): p. 2319-2330.

18. Otake, K., Ruggiero, D.A., Regunathan, S., Wang, H., Milner, T.A., Reis, D.J., 1998. Regional localization of agmatine in the rat brain: an immunocytochemical study. Brain Res. 787 (1), 1-14.)

19. Peters, D., Berger, J., Langnaese, K., Derst, C., Madai, V.I., Krauss, M., Fischer, K.D., Veh, R.W., Laube, G., 2013. Arginase and arginine decarboxylase - where do the putative gate keepers of polyamine synthesis reside in rat brain? PLoS One 8 (6), e66735.

20. AndiaraE.Freitasa,b,n, VivianB.Neisb, AnaLúciaS.Rodriguesb Agmatine, a potential novel therapeutic strategy for depression European Neuropsychopharmacology(2016) 26, 1885-1899.
21. Pålsson E, Fejgin K, Wass C, Klamer D, Agmatine attenuates the disruptive effects of phencyclidine on prepulse inhibition. Eur. J. Pharmacol., 2008. 590(1): p. 212-216.

22. Uzbay T, Kayir H, Goktalay G, Yildirim M, Agmatine disrupts prepulse inhibition of acoustic startle reflex in rats. Hum Psychopharmacol, 2009.

23. Arıcıŏ̆lu F, Agmatinin nöropsikiyatrideki yeri ve önemi RCHP 2009. 3(1-2): p. 7-14.

24. Jing $Y$, Zhang $H$, Wolff A R, Bilkey D K, Liu P, Altered arginine metabolism in the hippocampus and prefrontal cortex of maternal immune activation rat offspring. Schizophr Res, 2013. 148(1): p. 151-156.

25. Liu P, Jing Y, Collie N, Dean B, Bilkey D, Zhang H, Altered brain arginine metabolism in schizophrenia. Transl Psychiatry., 2016. 6(8): p. e871.

26. Stewart L S,McKay B, Acquisition deficit and time-dependent retrograde amnesia for contextual fear conditioning in agmatine-treated rats. Behav Pharmacol, 2000. 11(1): p. 93-97.

27. Aricioglu F,Altunbas H, Is agmatine an endogenous anxiolytic/antidepressant agent? Ann. N. Y. Acad. Sci., 2003. 1009(1): p. 136-140.

28. Zomkowski A D, Hammes L, Lin J, Calixto J B, Santos A R S, Rodrigues A L S, Agmatine produces antidepressant-like effects in two models of depression in mice. Neuroreport, 2002. 13(4): p. 387-391.

29. Zeidan M P, Zomkowski A D, Rosa A O, Rodrigues A L S, Gabilan N H, Evidence for imidazoline receptors involvement in the agmatine antidepressant-like effect in the forced swimming test. Eur. J. Pharmacol., 2007. 565(1): p. 125-131.

30. Budni J, Gadotti V M, Kaster M P, Santos A R, Rodrigues A L S, Role of different types of potassium channels in the antidepressant-like effect of agmatine in the mouse forced swimming test. Eur. J. Pharmacol., 2007. 575(1): p. 87-93.

31. Taksande B G, Kotagale N R, Tripathi S J, Ugale R R, Chopde C T, Antidepressant like effect of selective serotonin reuptake inhibitors involve modulation of imidazoline receptors by agmatine. Neuropharmacol., 2009. 57(4): p. 415-424.

32. Bernstein H-G, Stich C, Jäger K, Dobrowolny H, Wick M, Steiner J, Veh R, et al., Agmatinase, an inactivator of the putative endogenous antidepressant agmatine, is strongly upregulated in hippocampal interneurons of subjects with mood disorders. Neuropharmacol. , 2012. 62(1): p. 237-246.

33. Zhu M Y, Wang W P, Huang J, Regunathan S, Chronic treatment with glucocorticoids alters rat hippocampal and prefrontal cortical morphology in parallel with endogenous agmatine and arginine decarboxylase levels. J. Neurochem., 2007. 103(5): p. 1811-1820.

34. Meylan E, Breuillaud L, Seredenina T, Magistretti P J, Halfon O, Luthi-Carter R, Cardinaux $J$, Involvement of the agmatinergic system in the depressive-like phenotype of the Crtcl knockout mouse model of depression. Transl Psychiatry., 2016. 6(7): p. e852.

35. Zhu M Y, Wang W P, Cai Z W, Regunathan S, Ordway G, Exogenous agmatine has neuroprotective effects against restraint-induced structural changes in the rat brain. Eur. J. Neurosci., 2008. 27(6): p. 1320-1332.

36. Sevinç Ş S, Dalbudak E, Aldemir S, Özer İ, Akıncı Ş, Topcu M, Manic Episode Induced By Arginine, Lysine and Ornithine use. Psychopharmacol Bull, 2012. 22(1): p. S77.

37. Yilmaz E, Sekeroğlu M R, Yllmaz E, Cokluk E, Evaluation of Plasma Agmatine Level And Its Metabolic Pathway In Patients With Bipolar Disorder During Manic Episode And Remission Period. Int J Psychiatry Clin Pract,DOI:10.1080/13651501.20191569237.. 